6. Hrabovetska, O. A. (2013). Bio chemical and medical features of Asimina triloba (L.) Dunal. Perspective ways of science research of medical and technical crops. Lubny, 20-22.

7. Vasyliev, A. E., Voronin, N. S., Elenevsky, A. H. et. al (1988). Botany: Morphology and anatomy of crops. Moscow, 480.

8. Cherevchenko, T. M., Rakhmetov, D. B., Haponenko, M. B. (2012). Preservation and enriching of crop resources by introduction, selection and bio technologies. Kyiv: Phyto centre, 432.

9. Fedorov, A. A. (Ed.) (1974, 1978, 1980). The life of crops in sixissues. Vol. 1, Vol. 4, Vol. 5. Moscow: Prosveshhenie, 487, 447, 430.

10. Bulakh, P. Y. (2007). The theoretical basics of optimization of introduction process. Kyiv, 31.

11. Hornostaev, H. N. (1970). Insects of USSR. Moscow, 372.

Рекомендовано до публікачії науково-технічною радою Хорольського ботанічного саду Дата надходження рукопису 18.05.2016

Красовський Володимир Васильович, кандидат біологічних наук, старший науковий співробітник, Директор, Хорольський ботанічний сад, вул. Кременчуцька, 1/79, м. Хорол, Україна, 37800

E-mail: horolbotsad@gmail.com

\title{
UDC 551.553.8:582.526.3+591.524.1:591.131.15
}

\section{DECOMPOSITION DYNAMICS OF THE WRACK OF DIFFERENT ORIGIN IN THE BLACK SEA SANDY LITTORAL}

\author{
(C) B. Alexandrov, V. Dyadichko, O. Garkusha, G. Ivanovych, N. Kopytina, A. Kurilov, \\ L. Nidzvetska, S. Nikonova, A. Tropivska, I. Serbinova
}

The role of sand interstitial community in process of decomposition of different origin wrack (seaweed, seagrass and mussel) are considered in with the results of laboratory experiments. Quantitative changes of organic matter content, bacteria, marine fungi, microalgae, flagellates, ciliates and insects in wrack and underlying sand are studied. The results obtained in the laboratory closed to the natural conditions

Keywords: decomposition, wracks, organic matter, microorganisms, ciliates, insects

\begin{abstract}
Виерше проведено комплексне дослідження розкладу штормових викидів (ШВ) різного походження угрупованням гідробіонтів піщаної інтерстіииалі. У лабораторному експерименті в ШВ і у піску, під ШВ, вивчали вміст органічної речовини, бактерій, морських грибів, мікроводоростей, джгутикових, інфузорій і комах. Показані особливості впливу ШВ різної природи на різноманітність і кількісний розвиток гідробіонтів піщаної інтерстіциалі. Результати, отримані в лабораторних умовах, близькі до природних умов
\end{abstract}

Ключові слова: итормові викиди, інтерстіциаль, органічна речовина, мікроорганізми, інфузорії, комахи

\section{Introduction}

Sandy beaches can act as a biogeochemical reactor. Water filtering through the beach sands promotes organic matter (OM) decomposition [1-3]. At the same time OM content is closely linked with the granulometric composition of the soil [4]. In spite of a big amount of research works devoted to sandy beach ecosystems $[5,6]$, a little attention was paid to the comprehensive research of storm wrack decomposition by the all sand inhabitants because of the methodical difficulties in such a study.

\section{Literature review}

Decomposition of macrophyte wrack and their contribution to the energetics of coastal ecosystems has been studied both "in vivo" and "in vitro" since the end of the last century [7]. Interest in this issue doesn't fall down currently [8]. It is shown that a full range of organisms from bacteria to macrofauna takes part in the pro- cess of wrack decomposition. Bacterial intensive colonization takes place at the early stages what initiates processes of entire OM mass decomposition through the macrophytes cells lysis, where $23-27 \%$ of the OM mass are converted into bacterial biomass in situ, and the rest is mineralized with the interstitial microorganisms participation [9]. Probably, because of this considerable amount of various nitrogen forms, entering supralittoral with wrack, are not accumulated in the beach sand $[10,11]$.

Being a part of the algae mucous compounds, OM decomposes unevenly: $50 \%$ mannitol utilization observed within 48 hours, whereas alginates and polysaccharides - within 6-10 days in the experiment $[12,13]$. Circulation of soluble compounds of decaying thallomes with bacterial destruction occurs much faster and is carried out by free-living bacteria associated with macrophyte surface. Whereas bacteria associated with their solid remains participate in the transformation and energy 
transfer to higher trophic levels, as food for flagellates, ciliates and amoebas [14].

It is shown that the maximum bacterial biomass is observed on the 7-10th day of exposure and regulated by consumers. In total $44 \pm 4 \%$ of decomposing OM is soluble, and the remaining part forms detritus [7]. The algal mass enriched with soluble OM, bacteria, fungi and their exometabolites becomes available for heterotrophic flagellates and ciliates. Other utilizers of detritus and dissolved OM: crustaceans, insects, birds, etc., including predators $[15,16]$ also populate the decaying algae. The dynamics of food flows in coastal ecotone depends not only on the number of wrack, but also on the constituent species [8].

As decomposers bacteria are actively involved in OM transformation and stimulate the development of interstitial microbiota. Wrack colonization by the coccus bacteria leads to macrophyte cells lysis and colonization by the bacterial rods [9]. In the Black Sea the influence of plant wrack on its ecological condition was studied in Anapa bay, as a pattern. The main attention was paid to the study of the species diversity of "unattached macrophytes", as well as to the dynamics of their stocks in the coastal zone [17]. Macrophytes wrack in Europe and Southeast Asia countries are considered as valuable fertilizer and widely used in agriculture [18]. However, changing the content of OM both in algae wrack and sand coastal sediments as well as succession of interstitial organisms community involved in its degradation has not been studied.

Wrack of animal origin (half-dead and dead invertebrates, fishes) is also eliminated with the participation of microorganisms. Land animals (insects, birds, etc.) also take part in the process of utilization. However, a little research is devoted to this aspect of the wrack destruction in the available literature.

The aim of this paper is to reveal differences in the dynamics of wrack decomposition of different nature (algae, macrophytes, higher aquatic plants, invertebrates) and examine the participation of sand interstitial organism communities in this process.

\section{Material and Methods}

Three laboratory one-scheme experiments with wrack of macrophyte algae, mussels and higher aquatic plant Zostera were conducted during a year. To study the successional changes rate of the Black Sea sandy mediolittoral communities, associated with the wreck decomposition, experiments were carried out in the conditions similar to the natural. The decomposition of algae was studied in winter, mussels - in summer, and wrack of eelgrass - in summer and autumn - during the seasons when wrack of the corresponding nature were presented on the shore. In each experiment, 4 non-toxic containers $30 \times 40 \times 20 \mathrm{~cm}$ in size, were filled with an equal amount of $5 \mathrm{~cm}$ sand layer, taken simultaneously in the coastal zone of the surf. Into the first reference container (control) wrack was not placed, and in the rest containers wrack were laid on the top of the sand in a weight ratio $4: 2: 1$. Thus, in each of the 3 conducted experiments the content of investigated wrack was presented in three versions: 40 (var. 1), 20 (var. 2) and 10 (var. 3) $\mathrm{kg} \cdot \mathrm{m}^{-2}$. Experiments were carried out on the open balcony of the lab at a distance of about $2 \mathrm{~km}$ from the sea, at ambient temperature. Before the experiment start the sand was moistened with sea water, taken at the coastal water line. Humidity of the sand and stable salinity of pore water was supported by a continuous influx of distilled water (instead of evaporated) from the fixed reservoir connected with the sand and designed as a drinking bowl for birds. Sampling in experiments 1 and 3 was taken weekly, and in the 2 nd experiment - on the $2 \mathrm{nd}, 4 \mathrm{th}, 7 \mathrm{th}, 10 \mathrm{th}, 14 \mathrm{th}$ and $21 \mathrm{st}$ days. Differences in the frequency of the sampling were related to the different rates of substrates decomposition of plant or animal origin.

$\mathrm{OM}$ in wrack and sand were determined by combustion in a muffle kiln. Samples of plant wrack were carefully dried on a hotplate, and then burned in a muffle kiln at dark red heat (temperature $450-500{ }^{\circ} \mathrm{C}$ ) within 2 hours to a homogeneous dark ash color without inclusions and constant weight [19]. Sand samples were burned at $650{ }^{\circ} \mathrm{C}$ within 8 hours. The difference between the initial and final weight obtained after combustion was a mass of OM [20]. The content of OM in wrack was evaluated as \% of dry weight (DW). To determine OM in wrack of animal origin (milled live mussels), they were dried in an oven at $105{ }^{\circ} \mathrm{C}$, and then burned in a muffle kiln at $450-500{ }^{\circ} \mathrm{C}$ within 5 hours [21]. OM quantity was evaluated in $\mathrm{mg}(\mathrm{DW}) \cdot \mathrm{cm}^{-3}$.

The numbers of saprotroph (OM indicator) and bacteria mineralizing organic phosphorus compounds were calculated in the sand under wrack. The first group of saprotroph was counted by the number of colonies grown on the surface of the FPA medium after incubation of inoculated sand at $20-22{ }^{\circ} \mathrm{C}$ within 48 hours, and the determination of the second one was performed on the medium with calcium glycerophosphate after 5 days of incubation at $28^{\circ} \mathrm{C}$ [22].

The study of mycobiota was carried out by the direct count method. A sample of sand was placed in a 3-10 $\mathrm{ml}$ of water and stirred for $5 \mathrm{~min}$. The resulting suspension for fungi quantity determination was observed at magnification of $\times 400$. No less than $0.06 \mathrm{ml}$ ( 3 coverglass $18 \times 18 \mathrm{~mm}$ ) was tested in each case. Spores and hyphae biomass was calculated by multiplying their volume by the specific density of 1.20 and $1.05 \mathrm{~g} / \mathrm{cm}^{-3}$ respectively. The propagules volume was calculated by the formula of geometric similarity [23, 24]. Morphobiological structure of microcomplexes was evaluated by the percentage of fungi mycelium and spores in the total biomass.

Standard methods applying in the studies of microphytobenthos were used in the research of microalgae $[25,26]$. The biomass was determined by calculating the true volumes of cells [27]. Permanent preparations of valvula were made for identification of diatoms [28]. 
For the study of heterotrophic flagellates $2-3 \mathrm{ml}$ of sterile sea water were added to the sand samples of a certain volume. The samples were stirred gently in a circular motion and separated seawater containing flagellates were examined under the microscope at magnification of $\times 100-400$. The identification of heterotrophic Euglenids is according to guides [29, 30]. The generic identities of free-living heterotrophic flagellates are covered by Al-Yamani [32] and Mylnikov [33], and the following items are useful guides to many species descriptions: [34, 35].

Ciliates were extracted from the sand by ice according the method of Uhlig [36]. Calculation in the extract was carried out under a stereo microscope. Biomass was calculated by volume-weighted method [23]. The identification was carried out on alive and fixed preparations impregnated with silver $[37,38]$ using the identification key for interstitial ciliates [39].

Sampling of all microbiota components in the sand was made by a sterile tube to its full depth $(5 \mathrm{~cm})$ in three replications. Calculation of quantity and biomass was carried out for $1 \mathrm{~cm}^{3}$ of sand. Quantitative samples of entomofauna were picked out weekly using container with the inlet area of $28.26 \mathrm{~cm}^{2}$. Insects were separated from the substrate by the flotation method, and then the specimens were counted in a Petri dish under a stereomicroscope. The number of insects was counted per cubic decimeter of substrate. The biomass was determined by weighing on the torsion balance.

\section{Results}

The main results of the experiments are presented in the order of their performing.

\subsection{1.-4.03.2012)}

Wrack were collected in the coastal zone of Odessa Bay and consisted of green algae Cladophora spp. and Enteromorpha spp. Due to the frosty weather set in February, the experiment arbitrarily consisted of two parts before wrack and sand freezing (5.01.-24.01. 2012) and after their thawing at a temperature of $>0{ }^{\circ} \mathrm{C}(28.02$.3.04. 2012).

The maximum rate of $\mathrm{OM}$ consumption in the sand under wrack was recorded immediately after wrack and sand thaw. If the average speed of OM reduction on 16.03.2012 was $0.16 \%(\mathrm{DW}) \cdot \mathrm{d}^{-1}$, then in 4 days after that it was $1.31 \%(\mathrm{DW}) \cdot \mathrm{d}^{-1}$. We recorded the reduction of $\mathrm{OM}$ in the sand more than twice from 9.9 to $19.8 \mathrm{mg}$ (DW) $/ \mathrm{cm}^{-3}$, and also the maximum reduction of OM content in wrack of macrophytes from 66.6 to $34.2 \mathrm{mg}$ (DW) $\mathrm{cm}^{-3}$. For all variants of the experiment on average during 69 days OM content in algae decreased from 68 to $8 \mathrm{mg}(\mathrm{DW}) \cdot \mathrm{d}^{-1}$, i. e. by $88 \%$ (Fig. $1, a$ ). In the mean, regardless of the experiment variant, organic content in the sand was $1.91 \pm 0.32 \%$ of its amount in wrack.

Development of bacteria in the sand under the algal debris was observed after thawing. The algae stimu- lated the development of saprotrophic bacteria reached on average the number of $1.78 \pm 0.91 \mathrm{~m}$ colony-forming units (CFU) $\mathrm{cm}^{-3}$ (excess the control 5.8 times). A similar pattern was observed in bacteria that mineralize organic phosphorus compounds - under the wrack their density was $0.33 \pm 0.08 \mathrm{~m} \mathrm{CFU} \cdot \mathrm{cm}^{-3}$ of sand, which exceeded the control 2.1 times. Maximum bacterial growth was observed in 2 weeks after thawing if the temperature reached $2{ }^{\circ} \mathrm{C}$ (Fig. $1, b-c$ ).

In the sand under wrack 12 species of 7 micromycetes genera, Fungi spp. spores and mycelium were found. The freezing of the substrate led to the decrease of microbiota to a minimum. Despite the slight decrease of the organic content in the sand, quantitative indicators of mycobiota increased. In the sand of the control propagules medium biomass was $(0.35 \pm 0.08) 10^{-3} \mathrm{mg} \cdot \mathrm{m}^{-3}$, while in the experiment it was 30 times higher $(9.44 \pm 3.33) 10^{-3} \mathrm{mg} \cdot \mathrm{cm}^{-3}$ (Fig. 1, $d$ ) on average.

In microalgae composition 32 species (Bacillariophyta -27 , Chlorophyta -3 , Cyanoprocaryota -2 ) were recorded. The biomass of microalgae under the wrack was higher than in the control. With the increase of the exposure period, their biomass in the control gradually increased to $(0.23-0.43) 10^{-3} \mathrm{mg} \cdot \mathrm{cm}^{-3}$, however, the average biomass of algae in the sand from wrack was almost 7 times higher than the control and was $(0.68 \pm 0.35) 10^{-3} \mathrm{mg} \cdot \mathrm{m}^{-3}$ (Fig. 1,e).

Among flagellates 55 species were observed, and their diversity in the experiment variants was 1.55 times higher than in the control (45 and 29 species, respectively). During the first week the rapid development of flagellates was recorded; their number in the experiment was 3.5 times, and the species composition 5.7 times higher than the corresponding figures in the control. Temperature lowering led to the reduction of the quantitative but not qualitative composition - the number exceeded 1.3 times, and species richness remained at the same level. In the control after a period of freezing population growth occurred at a higher rate, but further in the sand under wrack quantity was on average 1.5 times higher than in the control. The dynamics of growth in the control and in the experiment, was undulating, a maximum of flagellates development was recorded on the forth week after thawing. Maximum numbers of flagellates in the experiment was 24,740 ind $\cdot \mathrm{cm}^{-3}$ on average $-11920 \pm$ \pm 6420 ind $\cdot \mathrm{cm}^{-3}$ (Fig. 1, f).

A fairly high species richness of ciliates was recorded before cuvettes freezing: during the first and second samplings the amount of species in the sample was 1-9 (on average $-7 \pm 2$ ) and 11-17 (on average $13 \pm 1$ ), respectively. Probably, under the experimental conditions, where the pool of resting phases is limited, and freezing as compared to natural conditions was greater a part of the species was eliminated because of the death of resting stages. In general, the maxima in the control and experiment variants coincided what pointed on the impact of external factors, such as temperature (Fig. 1, $g$ ). 


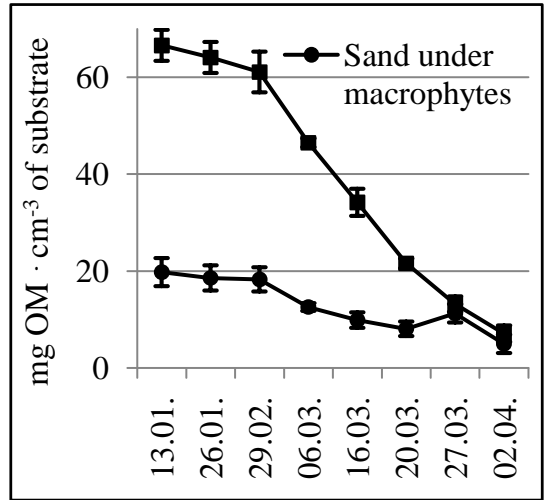

$a$

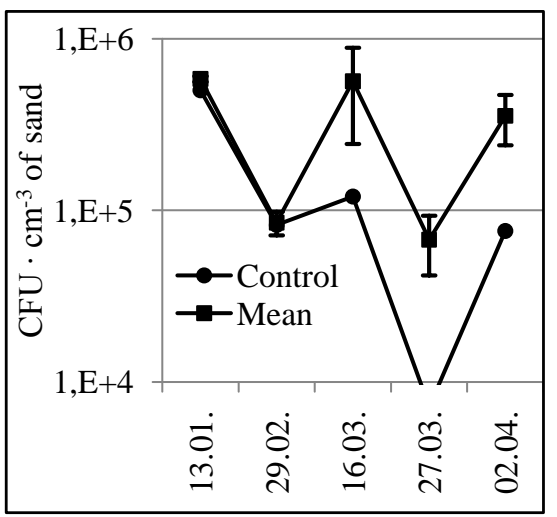

$c$

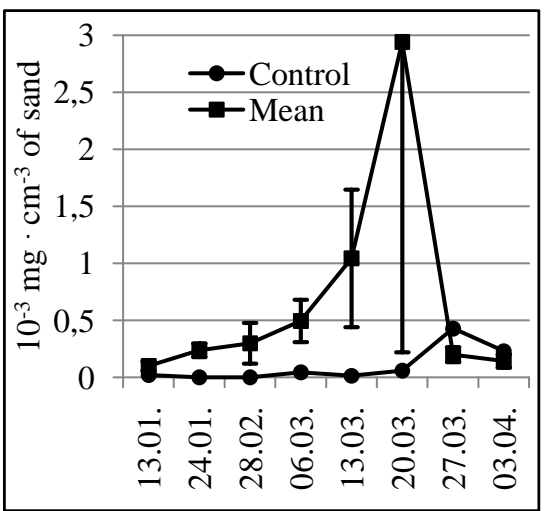

$e$

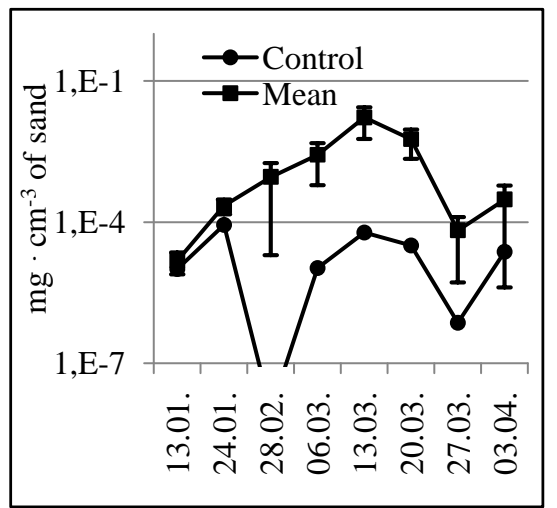

$g$

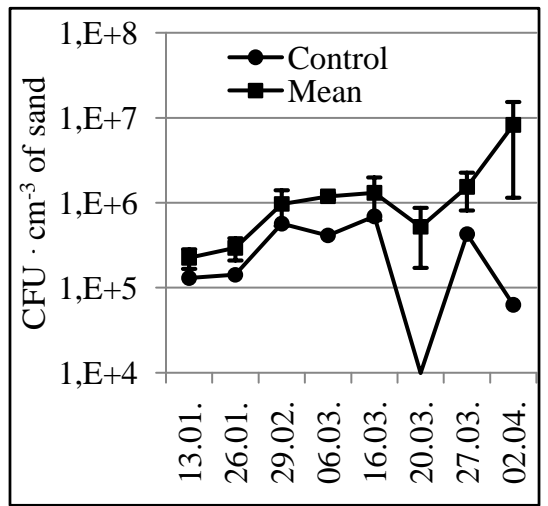

b

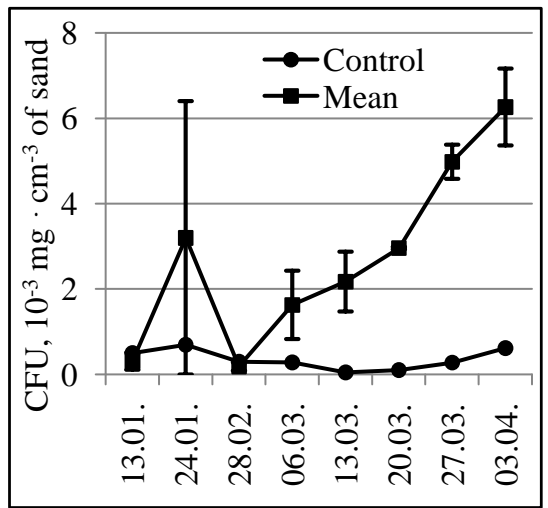

d

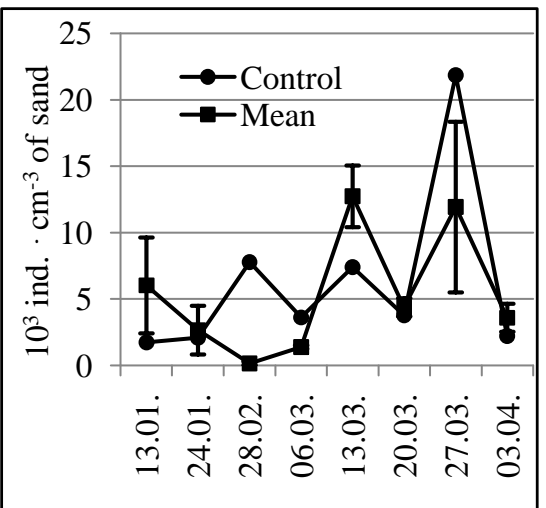

f

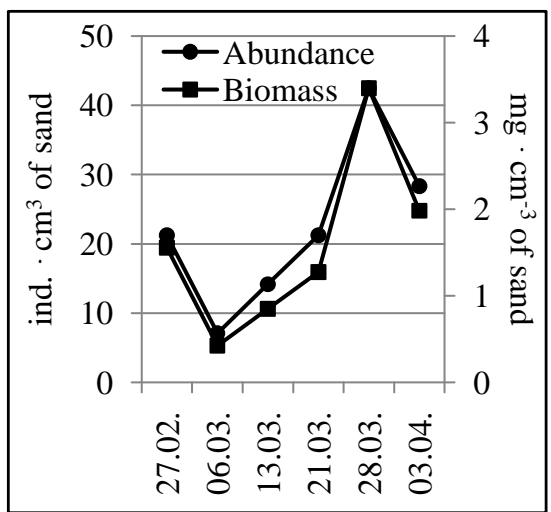

$h$

Fig. 1. Experiment on green-algae decomposition on the sand: $a$-dynamics of organic matter content; $b$ - saprotroph bacteria development; $c$ - phosphate mineralizing bacteria development; $d$ - fungi development; $e$ - microalgae development; $f$-heterotrophic flagellates development; $c$ - ciliates development; $h$-insects development.

Hereinafter: the abscissa - the date of the sampling, error bars - standard error 
In the sand under wrack springtails (Collembola), Diptera larvae and the beetle Philontus spinipes Sharp, 1874 (Coleoptera, Staphylinidae) were found. Representatives of the first two groups belong to the specialized inhabitants of interstitial - to saprophages or polyphages respectively. They formed almost the entire number of entomofauna species. $P$. spinipes refers to polytopic predator preying on a variety of invertebrates that feed on decaying organic remains; this species is found in different habitats and does not have stable relations with wrack. Only once it was reordered in the samples. The first insects from the exposing samples were recorded on 27.02.2012. At that time the entomofauna quantity was 21.23 ind. $\cdot \mathrm{dm}^{-3}$, the biomass $-1.56 \mathrm{mg} \cdot \mathrm{dm}^{-3}$. Then, in a week after thawing, quantitative development of the insects decreased twice, reaching quantity of 7.07 ind. $\mathrm{dm}^{-3}$ and $0.42 \mathrm{mg} \cdot \mathrm{dm}^{-3}$. Insects quantitative characteristics began to rise again with temperature increasing, and three weeks later peaked -42.46 ind. $\mathrm{dm}^{-3}$ and $5.94 \mathrm{mg} \cdot \mathrm{dm}^{-3}$. After that, the number of entomofauna representatives decreased again to 28.31 ind. $\mathrm{dm}^{-3}$. At that time the biomass was $1.13 \mathrm{mg} \cdot \mathrm{dm}^{-3}$ (Fig. $1, h$ ).

\section{2. Mussel wrack (13.06.-09.07.12)}

To simulate the fresh emissions druzes of live shellfish sampled in the sea were roughly milled and used in the experiment variants similar to wrack of plant origin.

During the first two days after the onset of exposure maximum number of OM permeated into the sand, increasing its starting content in 1.7 times (on average to $8.4 \mathrm{mg}$ (DW) $\mathrm{cm}^{-3}$ ). The main body of OM got into the sand during 22 days from the start of exposure. During this time the organic content of mussel wrack decreased from 38.4 to $11.2 \mathrm{mg}(\mathrm{DW}) \cdot \mathrm{cm}^{-3}$, and in the sand - up to $4.0 \mathrm{mg}$ (DW) $\mathrm{cm}^{-3}$ (Fig. 2, a). On average, irrespective of the experiment variants, organic content of the sand was $1.61 \pm 0.03 \%$ of its amount in wrack.

The number of saprotrophic bacteria varied in 2-3 orders, and depended in direct proportion to the mass of mussels in variants of the experiment. Their maximum number in the sand reached $65.7 \mathrm{~m}$. CFU $\cdot \mathrm{cm}^{-3}$ (on average $\left.14.9 \pm 4.1 \mathrm{~m} . \mathrm{CFU} \cdot \mathrm{cm}^{-3}\right)$, what 3.3 times exceeded the control $\left(4.5 \pm 3.0 \mathrm{~m}\right.$. CFU $\left.\cdot \mathrm{cm}^{-3}\right)$, if we eliminate the anomalous increasing of number in the control to 220 million $\mathrm{CFU} \cdot \mathrm{cm}^{-3}$ on the 12 th day of the experiment. Mussels more pronounced stimulated the development of phosphate mineralizing bacteria, which numbers reached $13.0 \pm 3.0 \mathrm{~m}$. CFU $\cdot \mathrm{cm}^{-3}$, differing from the control 12.2fold (Fig. 2, $b-c$ ). It is known that bacteria rapidly reproduce on substrates of animal origin with medium alkalizing in the process of decomposition what was observed in the experiment, with medium $\mathrm{pH}$ changing from 5.5 to 7.0.
In the sand under mussels spores of 11 micromycetes species from 8 genera, Fungi spp. spores and mycelium cells were recorded. In $44.8 \%$ of the samples propagules of fungi were absent, in $13.8 \%$ - sporadic spores were found. The biomass of propagules in the control ranges from 0 to $0.3210^{-3} \mathrm{mg} \cdot \mathrm{cm}^{-3}$; under wrack it varied in the range of $0-0.9710^{-3} \mathrm{mg} \cdot \mathrm{cm}^{-3}$. In the experiment the conditions for mycobiota development began to form on the third week, and only on the sixth week the intensive growth of the mycelium was recorded in all variants (Fig. 2, $d$ ).

In total 23 species of microalgae (Bacillariophyta -11 , Chlorophyta - 6, Cyanoprocaryota - 5, Cryptophyta -1 ) were found. With growth of exposure the biomass in the control and experimental variants increased due to the development of green and blue-green algae. Minimal biomass was registered in the control on the 24th day $\left(0.6810^{-3}\right.$ $\left.\mathrm{mg} \cdot \mathrm{cm}^{-3}\right)$ and in the experiment - on the 31st day $(0.027$ $\mathrm{mg} \cdot \mathrm{cm}^{-3}$ ). On average, the biomass under wrack was 8.2 times higher than in the control (Fig. 2,e). Diatom algae, both in the control and the experiment variants comprised the basis of the biomass on the 5-10th day of exposure; and from the 13th day and up to the completion of the experiment it was comprised with green and blue-green algae.

The number of flagellar species during the experiment was relatively low in the control and its variants. The number of flagellar species in control did not exceed 4 , and in the experiments it was 0-2 species per the sample, and their development started only on the 10th day. The maximum number of 9,700 ind. $\cdot \mathrm{cm}^{-3}$ was recorded in the control, in the variants of the experiment mean number was 2.2 times lower (Fig. 2, f).

Throughout the experiment, the ciliates species abundance was relatively low, both in the control and its variants, and in the control it was the highest. In the variants of the experiment it increased with decreasing of mussel's homogenate mass. Increase of wrack number simplified species structure of interstitial ciliofauna in proportion. In var. 1 ciliates were absent in the first two samplings; the maximum was observed in var. 3 due to the number explosion of Uronema sp. up to 20 thousand. ind. $\mathrm{cm}^{-3}$ in the sand (Fig. $2, \mathrm{~g}$ ) on the second day.

In the exposed wrack samples and in the underlying sands insects were presented only by dipterous larvae and pupae, mainly - commensal representatives of Muscidae. In the control throughout the experiment Diptera was not found. Quantitative development of insects was in proportion to the mussels mass in the wrack. The highest mean values of insects' numbers (68.75 ind. $\left.\cdot \mathrm{dm}^{-3}\right)$ and biomass $\left(149.63 \mathrm{mg} \cdot \mathrm{dm}^{-3}\right)$ were observed in var. 1 . The maximum larvae biomass was recorded on the 10th and 18th day from the beginning of the exposure, and then (in July) the biomass decreased, but the number increased to 106.16 ind. $\cdot \mathrm{dm}^{-3}$ (Fig. $2, h$ ). 


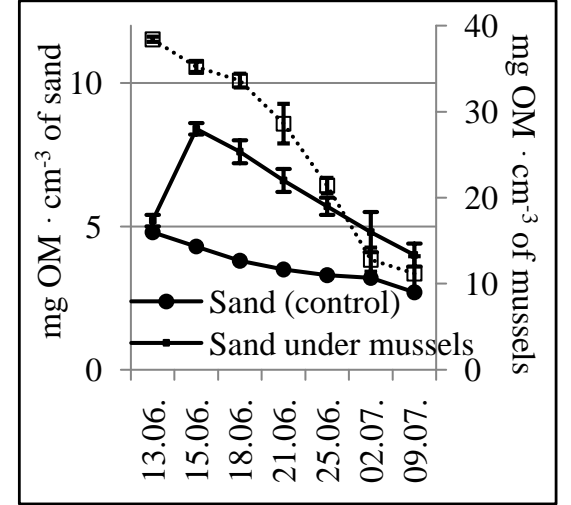

$a$

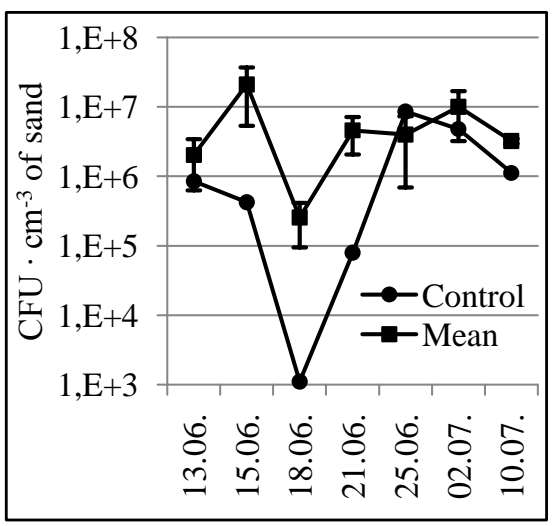

$c$
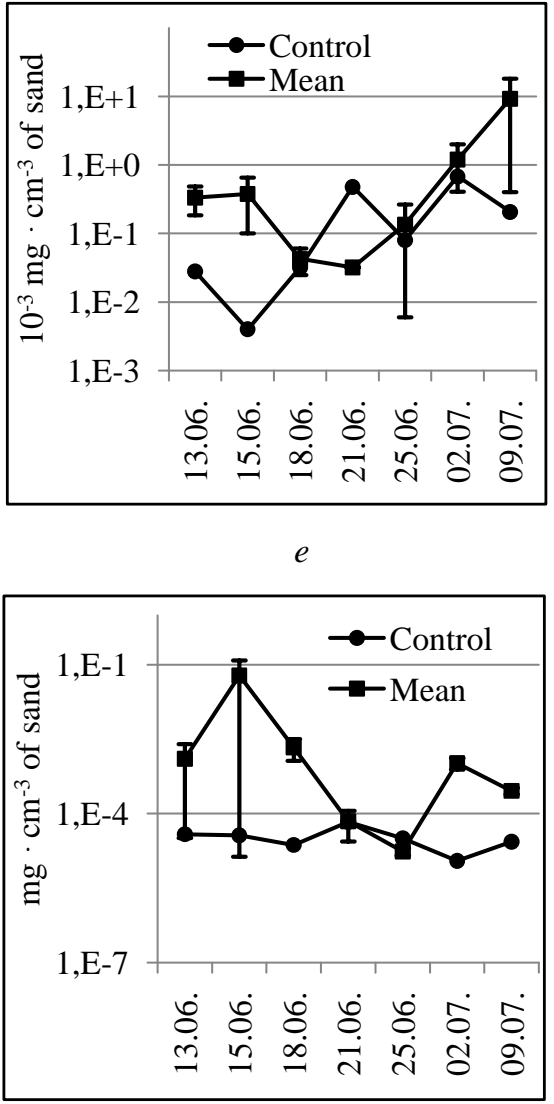

$g$

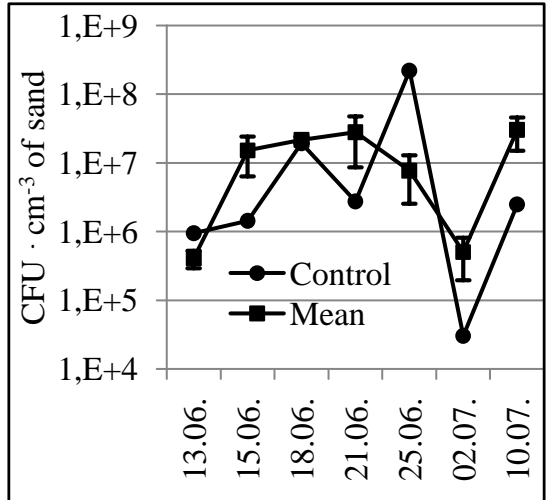

b

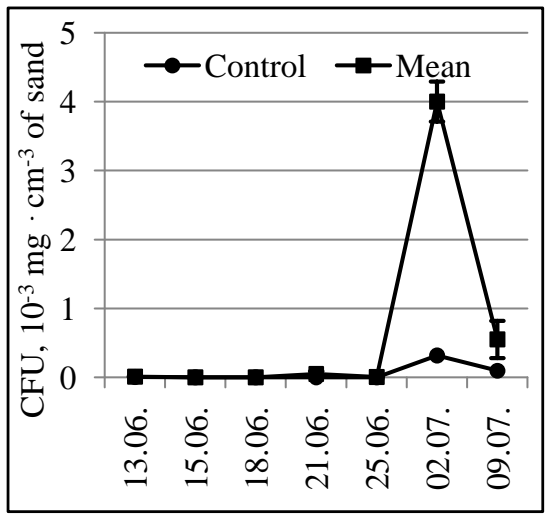

$d$

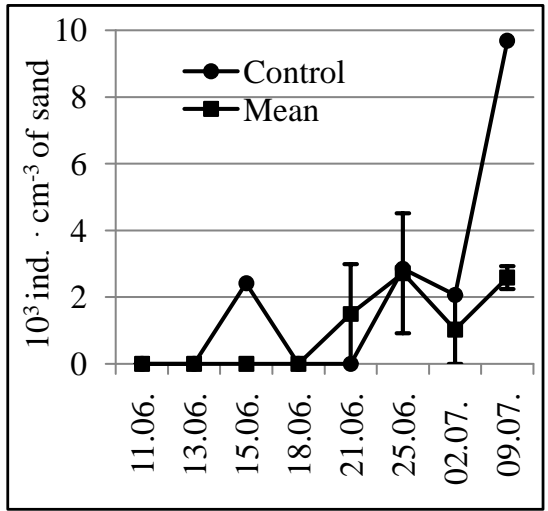

$f$

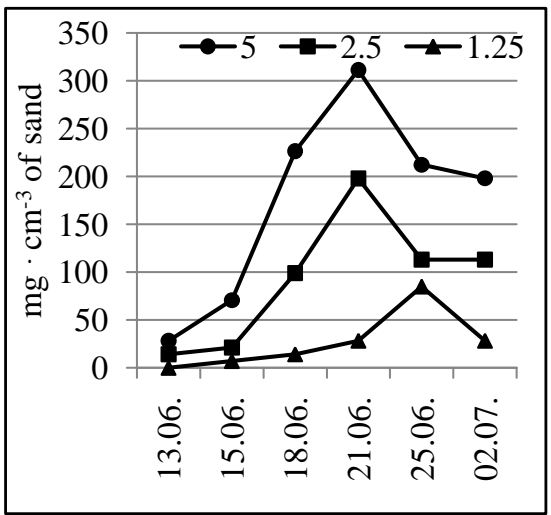

$h$

Fig. 2. Experiment on the mussels' decomposition on the sand: $a$-dynamics of the organic matter content; $b$ - saprotroph bacteria development; $c$ - phosphate mineralizing bacteria development; $d$ - fungi development; $e$ - microalgae development; $f$ - heterotrophic flagellates development; $g$ - ciliates development; $h$-insects development 


\section{3. Zostera wrack (29.08.-09.10.12)}

Throughout the experiment in the sand samples under Zostera gradual reduction of OM from 13.2 to $8.9 \mathrm{mg}(\mathrm{DW}) \cdot \mathrm{cm}^{-3}$ was recorded. In the analysis of Zostera within the first 14 days, the mass of OM remained almost at the same level $\left(101.7-104.7 \mathrm{mg}(\mathrm{DW}) \cdot \mathrm{cm}^{-3}\right)$ and only on the 21 st day a decrease of OM was recorded. On average for all of the experiment variants during 35 days a decrease of OM content in algae from 107 to $80 \mathrm{mg}$ (DW) $\mathrm{cm}^{-3}$ (Fig. 3, a) occurred. On average, regardless of the variants of the experiment, OM content in the sand was $3,82 \pm 1,61 \%$ of its amount in wrack.

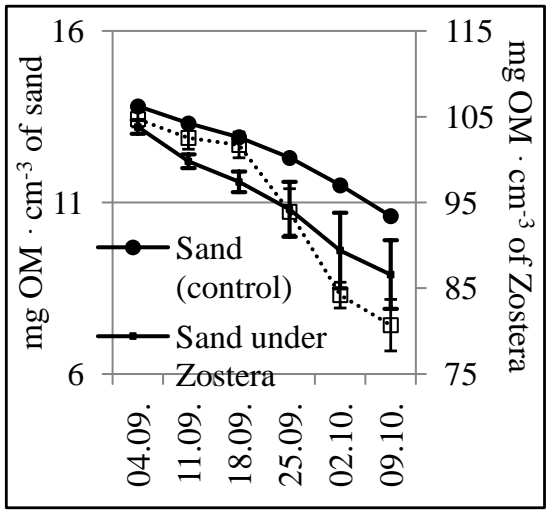

$a$

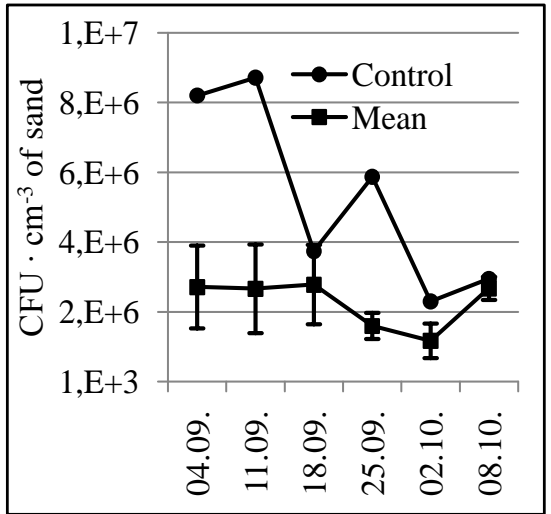

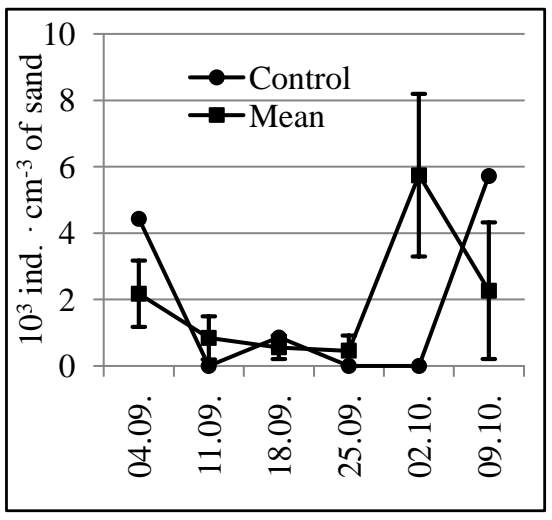

$e$

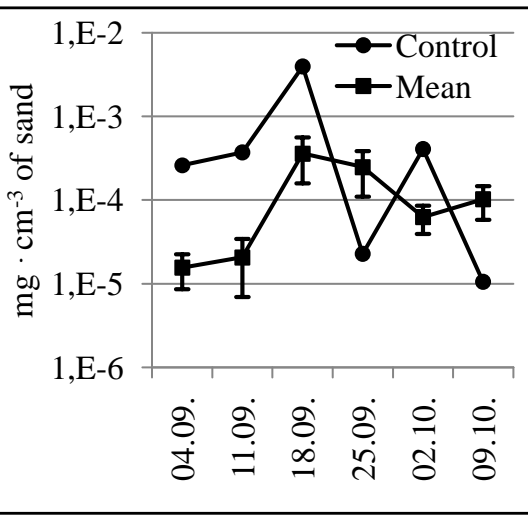

$f$

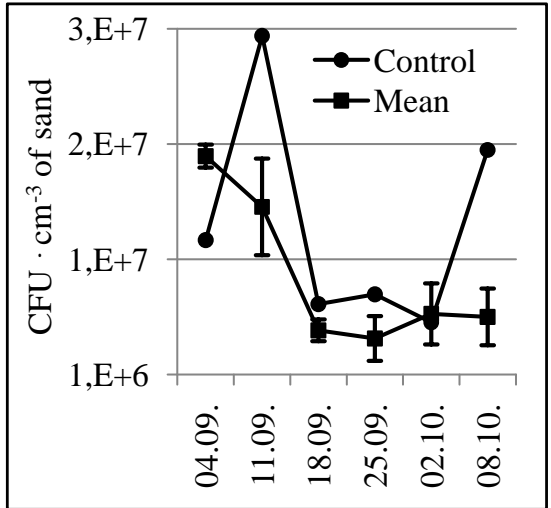

$b$

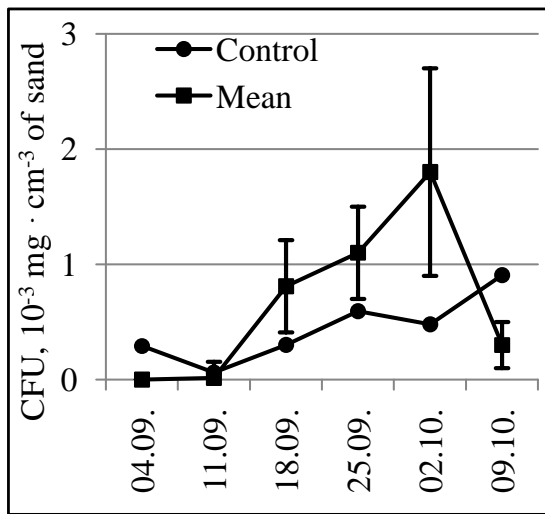

$d$

Fig. 3. Experiment on the eelgrass decomposition on the sand: $a$-dynamics of organic matter content; $b$-dynamics of saprotrophs bacteria; $c$-dynamics of phosphate mineralizing bacteria; $d$ - fungi development; $e$ - heterotrophic flagellates development; $f$ - ciliates development; $g$ - insects' development

The average number of saprotrophic bacteria was almost independent of Zostera concentration and remained at the same level of 9.3-9.7 m. CFU $\cdot \mathrm{cm}^{-3}$ in the sand. But in the variant with minimal mass bacterial growth was more intensive. In the control the group quantity was on averaged $14.0 \pm 3.9 \mathrm{~m}$. CFU $\cdot \mathrm{cm}^{-3}$ in the sand, which was almost 1.5 times higher than similar index in all three variants of the experiment. The average number of phosphate mineralizing bacteria was $0.76 \pm 0.17 \mathrm{~m}$. CFU $\cdot \mathrm{cm}^{-3}$, what was 1.1 times lower than in the control. Zostera made an inhibitory impact on bacterial growth (Fig. 3, $b-c$ ).

We recorded 17 species of micromycetes of 10 genera, Fungi spp. Spores and the mycelium cells. In the experiment, the mean biomass of fungal propagules 
was only $25 \%$ higher than in the control, reaching a value of $(0.585 \pm 0.195) \cdot 10^{-3} \mathrm{mg} \cdot \mathrm{cm}^{-3}$. The biomass increased with reduction of $\mathrm{OM}$ in Zostera and sand under the wrack (Fig. 3, d).

Twelve species of algae (Bacillariophyta -6 , Chlorophyta -2 , Cyanoprocaryota -3 , Cryptophyta -1 ) were found among microalgae. In the control they developed throughout the exposition, in the variants of the experiment they appeared in more than a month. The biomass of microalgae was several orders lower than in the control group. The maximum biomass of algae in the control was recorded on a 35th day and was only 0.002 $\mathrm{mg} \cdot \mathrm{cm}^{-3}$. Because of that, we failed to show the dynamics of microalgae in the presence of Zostera.

In the sand 19 species of flagellates were found. Neither control nor variants of the experiment were stable in species composition and quantitative development. Species abundance was low - on average 1.3-2.4 species per sample. Stick-slip nature of the quantitative development of flagellated from their absence to relatively high numbers $\left(8,480\right.$ ind. $\left.\cdot \mathrm{cm}^{-3}\right)$ was noted. The highest figures were registered on the 35 th day of the experiment (Fig. 3,e).

The maximum biomass of ciliates was registered in the control on the 14th day of the experiment $\left(0.004 \mathrm{mg} \cdot \mathrm{cm}^{-3}\right)$, what is about a factor of ten higher than in the variants with wrack where biomass changed simultaneously and differed little in terms of absolute values (Fig. 3, f).

In wrack and underlying sand, among insects, dipterous larvae and pupae mainly representatives of the Ephydridae family were found. Moreover springtails were met in some cases. Once (11.09.2012) in the control a representative of Staphylinidae family was found. The maximum values of the mean number $\left(62.28 \mathrm{ind} \cdot \mathrm{dm}^{-3}\right)$ and biomass $\left(103.33 \mathrm{mg} \cdot \mathrm{dm}^{-3}\right)$ were observed in var. 2 . Here the insects were already in the first sampling. In other cases the number and biomass were much smaller (Fig. 3, g).

\section{Discussion}

\section{1. Organic matter}

Organic matter of different nature wrack in all experimental variants and in annual volume of the organic carbon content was lower than on the sandy beaches of Australia and South Africa, but higher than on the sandy coast of India and Scotland [6]. It amounted to (46029900) $\mathrm{g} \mathrm{C}_{\mathrm{org}} \cdot \mathrm{m}^{-2}$, what was similar in macrophytes concentration on the coast of Anapa (600-7000) $\mathrm{g} \mathrm{C}_{\mathrm{org}} \cdot \mathrm{m}^{-2}$ [17]. The maximum rate of algae $\mathrm{OM}$ decomposition $\left(3.2 \%(\mathrm{SM}) \cdot \mathrm{d}^{-1}\right)$ and mussels $\left(3.0 \%(\mathrm{SM}) \cdot \mathrm{d}^{-1}\right)$ was detected in the var. 3 . In two weeks after the macrophytes experiment start $\mathrm{OM}$ in sand samples and wrack sequentially decreased. In the experiment with mussels during 2 days the amount of $\mathrm{OM}$ in sand samples increased in 1.7 times and then utilized, mainly by the bacterial community. OM content in mussel wrack decreased in 3.4 times during the study period. Gradual decrease of the OM volume in sand samples was noted along the experiment with Zostera. Intensive Zostera decomposition started in 21 day of the experiment. Maximum amount of
Zostera in the sand compared to the green algae and mussels wrack evidenced about its OM weak uptake.

\section{2. Bacteria}

Bacteria are actively involved in wrack decomposition. The maximum average number of saprotroph and phosphate mineralizing bacteria (14.88 and 6.44 million CFU $\cdot \mathrm{cm}^{-3}$ respectively) was detected in the sand under the mussels. Their minimal number of 0.94 and 0.33 million $\mathrm{CFU} \cdot \mathrm{cm}^{-3}$ was detected under algal wrack. Bacteria are known to multiply rapidly on substrates of animal origin owing to environment alkalizing in the process of substrate decomposition [40]. During the experiment on mussel decomposition $\mathrm{pH}$ changed from 5.5 to 7.0. The inhibiting effect of Zostera secretions on bacteria is a well-known fact [41].

\section{3. Fungi}

Hyphae biomass initially formed $37-50 \%$ in the sand under macrophytes. Along the experiment, regardless of fluctuations in the total number of propagules, hyphae biomass prevailed even during temperatures below $0{ }^{\circ} \mathrm{C}$ and formed $88.3 \%$ in the control and up to $100.0 \%$ in experimental groups. It evidenced about active algae destruction by fungi. Fungal biomass increased in 15 times in the sand in average. Biomass growth was $0.67 \cdot 10^{-3} \mathrm{mg} \cdot \mathrm{cm}^{-3} \cdot \mathrm{d}^{-1}$.

Mussel wrack had a little effect on microcomplex structure changing in the sand. Participation of fungi in the mussels' decomposition was marked on the third week of the experiment. High concentrations of mussels wrack had an inhibitory effect on fungi - the daily biomass growth was negative in var. 1. The maximum biomass growth $\left(0.04 \cdot 10^{-3} \mathrm{mg} \cdot \mathrm{cm}^{-3} \cdot \mathrm{d}^{-1}\right)$ was detected in var. 3 with a minimal wrack content.

Under Zostera wrack layer in the presence of low propagules amount the mycelium constantly dominated in biomass and its share in the control was $94.69 \%$. In the variants of the experiment relative mycelium share ranged from 62.58 to $92.74 \%$. Mycelium growth under a low number of fungal spores can be attributed to the influence of Zostera secretions on adhesion of spores [42]. The direct dependence of the intensity of fungi growth on the wrack mass testified their participation in Zostera decomposition. Maximum growth of fungal biomass $\left(0.15 \cdot 10^{-3} \mathrm{mg} \mathrm{cm}^{-3} \cdot \mathrm{d}^{-1}\right)$ was in var. 1 , and it was minimal $\left(0.04 \cdot 10^{-3} \mathrm{mg} \cdot \mathrm{cm}^{-3} \cdot \mathrm{d}^{-1}\right)$ in the var. 3. Thus, maximum fungi activity was observed in the decomposition of cellulose containing substrates - green algae and Zostera.

\section{4. Microalgae}

Microalgae demonstrated maximum sensitive respond to the macrophyte algae wrack decomposition, forming extremely high biomass $\left(0.080 \mathrm{mg} \cdot \mathrm{cm}^{-3}\right)$ on the 75 th day of exposure. Mussel wrack with maximum biomass of $0.027 \mathrm{mg} \cdot \mathrm{cm}^{-3}$ on the $31 \mathrm{st}$ days of exposure took the second place. Eelgrass wrack inhibited microalgae growth, which started only on the 35 th days. Their biomass was in 23-47 times less than in the control. Inhibition of microalgae by Zostera was described in the works of Harrison [43, 44]. 


\section{5. Flagellates}

Flagellates are the component of the community of interstitial sand microorganisms. Their development is determined not only by external factors such as the wrack type, but also internal ones caused by interaction with other species. It is known that heterotrophic flagellates form complex communities, including species which differ significantly in trophic preferences from trophic osmotrophs to predators and omnivores, food strategies, size and other environmental characteristics [45]. In an experiment with macrophytes the highest species diversity and abundance of flagellates was revealed. The nature of their quantitative development repeatedly changed by oscillation type what was probably caused by interaction of forming the community species. It was revealed in the experiment with the macrophytes wrack that flagellate number fluctuation had close ties with the number of saprophitic bacteria in the control and experiment variants and changed synchronously. In the experiment with mussels wrack the development of the flagellate did not reach high quantitative indices, indicating the adverse conditions for the development of this group of organisms. Perhaps flagellates were oppressed by the high concentration of OM biological degradation products of animal origin. In the experiment with the Zostera wrack number of flagellates in the sand under the wrack was minimal, probably due to the inhibitory effects of certain chemical components generated by Zostera decomposition.

\subsection{Ciliates}

Ciliates, unlike micro-algae and flagellates, showed a reduction in its development in the sand under studied wrack in a slightly different order: mussels, algae, macrophytes, and eelgrass. Under these substrates their maximum biomass was respectively as follows: $0.123 \mathrm{mg} \cdot \mathrm{cm}^{-3}, 0.038 \mathrm{mg} \cdot \mathrm{cm}^{-3}, 0.004 \mathrm{mg} \cdot \mathrm{cm}^{-3}$. OM wrack of animal origin had the strongest stimulating effect on quantitative indicators, however, an excess of food simplified the structure of ciliates species (maximum -8 species in the sample, the Pielou's uniformity index reached 0.96). Algae-macrophytes were the second in quantitative indexes, where the maximum number of species per sample $(17$ - prior to the period of frosty weather) and the maximum species diversity were recorded. Zostera wrack was on the third place on the effect on interstitial microfauna. The average biomass ratios in the control and experimental variants were significantly lower under the Zostera wrack, compared with experiments 1 and 2 . In most cases, the ratio was less than 1 , indicating the inhibitory effect of the components of the substrate decomposition. Only at the end of the experiment the biomass of ciliates in the experimental variants exceeded the control by 11-21 times. If in the experiments with macrophytes and mussels values of abundance and biomass were always positive in relation to the control, in the case of Zostera in all three variants they were negative with similar absolute values. The inhibitory effect was observed regardless of the substrate weight per sand area unit.

\section{7. Insects}

Insects in the experiment with macrophytes were presented by Collembola and Diptera larvae, which belong to specialized inhabitants of the interstitial, and according the trophic specialization - to saprophages or polyphages. They formed almost the entire number of entomofauna representatives. Insect development was observed in 8 days after sand and wrack thawing. Springtails usually dominated over dipterous larvae by the number in all samplings. The biomass ratio was reversed since dipterous larvae were of significantly higher weight than springtails (about $0.10 \mathrm{mg}$ vs. $0.06 \mathrm{mg}$ on average).

In the experiment with mussels highest mean number $\left(68.75\right.$ ind. $\left.\cdot \mathrm{dm}^{-3}\right)$ and biomass $\left(149.63 \mathrm{mg} \cdot \mathrm{dm}^{-3}\right)$ of dipterous larvae and puparia were found in var. 1. A trophic factor is crucial for choosing a site for breeding and Muscidae seek to settle the greatest concentration of food substrate.

On 10-20th day of the experiment, larger number of larvae reached the last age, what led to their maximum biomass amount. Later the reduction of biomass was due to the loss of material at the end of metamorphosis. Along with this we attributed the increase in number to the appearance of the first and second larval stage of new generation in the samples at that time.

In an experiment with Zostera dipteran larvae and pupae found in the samples belonged mainly to the semiaquatic (including coastal) family members of Ephydridae. The fact that the maximum values of the average abundance and biomass of insects were noted in var. 2 can probably be explained by optimal concentrations of nutrients for the development of their larvae.

\section{Conclusions}

1. In all variants of the experiment regardless of the temperature and wrack origin, the average volume of wrack $\left(20 \mathrm{~kg} \cdot \mathrm{m}^{-2}\right)$ caused the maximum decay rate of wrack (from 5.74 to $13.29 \mathrm{mg}(\mathrm{DW}) \cdot \mathrm{g}^{-1} \cdot \mathrm{d}^{-1}$ ) and decomposition rate of $\mathrm{OM}$ in the sand (from 0.17 to $\left.0.32 \mathrm{mg}(\mathrm{DW}) \mathrm{cm}^{-3} \cdot \mathrm{d}^{-1}\right)$.

2. Decomposition of the studied wrack excluding the temperature was determined by their origin and according their intensity was ranked in the following order: mussels, algae, macrophytes and eelgrass, respectively, $1.24,0.87$ and $0.77 \mathrm{mg}(\mathrm{DW}) \cdot \mathrm{cm}^{-3} \cdot \mathrm{d}^{-1}$; wrack of animal origin decomposed 1.5 times faster than of plant one.

3. The decomposition of mussel wrack provided the maximum stimulating effect on the growth of bacteria, ciliates, and insects; bimodal distribution of quantitative indicators of ciliates in the observations was associated with a high rate of decomposition of mussels and bacterial decomposition of recyclable nutrients, as evidenced by the maximum number of saprotrophic and phosphate mineralizing bacteria in the sand (65.7 and 13.0 million $\mathrm{CFU} \cdot \mathrm{cm}^{-3}$, respectively); the wrack had little effect on the fungi development which biomass in the presence of mussels was minimal, and growth was $0.016 \cdot 10^{-3} \mathrm{mg} \cdot \mathrm{m}^{-3} \cdot \mathrm{day}^{-1}$; high concentrations of decay products of $\mathrm{OM}$ of animal origin inhibited the development of flagellates. 
4. Decomposition of algal wrack had the maximum stimulating effect on micromycetes, microalgae and flagellates of interstitial sand: the average growth of the propagules biomass was $0.67 \cdot 10^{-3} \mathrm{mg} \cdot \mathrm{m}^{-3} \cdot \mathrm{d}^{-1}$; the greatest amount of microalgae biomass $\left(0.080 \mathrm{mg} \cdot \mathrm{cm}^{-3}\right)$, high species richness and abundance of flagellates 55 species, 24740 ind. $\cdot \mathrm{cm}^{-3}$ ) were registered; while a minimum number of saprotrophic bacteria was recorded under the wrack.

5. Wrack eelgrass decomposition in most cases had an inhibitory effect on the components of the mediolittoral sand community, in particular, the number of saprotroph and bacteria mineralizing organic phosphorus compound, in its presence, respectively, was 1.5 and 1.1 times lower than in the control; microalgae began developing only on the 35 th day of exposure and their biomass was 23-47 times less than in the control, ciliates maximum biomass was 10-30 times lower than in the presence of different nature debris.

6. The result of the inhibitory effect of the Zostera on hydrobionts was not only their minimum quantitative development in its presence, but the average amount of OM passed from wrack into the sand without mineralization was the highest $(3.82 \%)$, twice larger than for the algae and mussels.

\section{References}

1. Riedl, R. J. Hydrodynamic patterns in lotic intertidal sands and their bioclimatological implications [Text] / R. J Riedl, R. Machan // Marine Biology. - 1972. - Vol. 13, Issue 3. - P. 179-209. doi: 10.1007/bf00391378

2. McLachlan, A. Water filtration through reflective microtidal beaches and shallow sublittoral sands and its implications for an inshore ecosystem in Western Australia [Text] / A. McLachlan, I. G. Eliot, D. J. Clarke // Estuarine, Coastal and Shelf Science. - 1985. - Vol. 21, Issue 1. - P. 91-104. doi: 10.1016/0272-7714(85)90008-3

3. McLachlan, A. The interstitial environment of sandy beaches [Text] / A. McLachlan, J. Turner // Marine Ecology. 1994. - Vol. 15, Issue 3-4. - P. 177-211. doi: 10.1111/j.14390485.1994.tb00053.x

4. Snigireva, A. A. Impact of shore protection works on microflora of Odessa Gulf coast (Black Sea) [Text] / A. A. Snigireva, B. G. Aleksandrov // Research notes of Ternopol Univ. Ser. Biol. - 2010. - Vol. 3. - P. 253-256.

5. Knox, G. A. The ecology of seashores [Text] / G. A. Knox. - New York: CRC Press LLC, 2000. - 557 p. doi: $10.1201 / 9781420042634$

6. McLachlan, A. The ecology of sandy shores [Text] / A. McLachlan, A. C. Brown. - 2-nd ed. - Acad. Press, Elsevier, 2006. $-373 \mathrm{p}$.

7. Smith, B. D. An assessment of seaweed decomposition within a southern Strait of Georgia seaweed community [Text] / B. D. Smith, R. E. Foremann // Marine Biology. - 1984. - Vol. 84, Issue 2. - P. 197-205. doi: 10.1007/bf00393005

8. Mews, M. Species-specific decomposition rates of beach-cast wrack in Barkley Sound, British Columbia, Canada [Text] / M. Mews, M. Zimmer, D. E. Jelinski // Marine Ecology Progress Series. - 2006. - Vol. 328. - P. 155-160. doi: $10.3354 /$ meps 328155

9. Koop, K. Biodegradation and carbon flow based on kelp (Ecklonia maxima) debris in a sandy beach microcosm [Text] / K. Koop, R. C. Newell, M. I. Lucas // Marine Ecology Progress Series. - 1982. - Vol. 7. - P. 315-326. doi: 10.3354/ meps007315
10. McLachlan, A. Do sandy beaches accumulate nitrogen? [Text] / A. McLachlan, L. McGwynne // Marine Ecology Progress Series. - 1986. - Vol. 34. - P. 191-195. doi: 10.3354/ meps034191

11. Pregnall, A. M. Flux of ammonium from surf-zone and nearshore sediments in Nahant Bay, Massachusetts, USA in relation to free-living Pilayella littoralis [Text] / A. M. Pregnall, S. L. Miller // Marine Ecology Progress Series. - 1988. Vol. 50. - P. 161-167. doi: 10.3354/meps050161

12. Linley, E. A. S. Heterotrophic utilization of mucilage released during fragmentation of kelp (Ecklonia maxima and Laminaria pallida). I. Development of microbial communities associated with the degradation of kelp mucilage [Text] / E. A. S. Linley, R. C. Newell, S. A. Bosma // Marine Ecology Progress Series. - 1981. - Vol. 4. - P. 31-41. doi: 10.3354/ meps004031

13. Lucas, M. I. Heterotrophic utilization of mucilage released during fragmentation of kelp (Ecklonia maxima and Laminaria pallida). II. Differential utilization of dissolved organic components from kelp mucilage [Text] / M. I. Lucas, R. C. Newell, B. Velimirov // Marine Ecology Progress Series. - 1981. - Vol. 4. - P. 43-55. doi: 10.3354/meps004043

14. Stuart, V. Heterotrophic utilization of particulate matter from the kelp Laminaria pallida [Text] / V. Stuart, M. I. Lucas, R. C. Newell // Marine Ecology Progress Series. 1981. - Vol. 4. - P. 337-348. doi: 10.3354/meps004337

15. Chilton, E. W. Invertebrate communities associated with Bangia atropurpurea and Cladophora glomerata in western Lake Erie [Text] / E. W. Chilton, R. L. Lowe, K. M. Schurr // Journal of Great Lakes Research. - 1986. - Vol. 12, Issue 3. P. 149-153. doi: 10.1016/s0380-1330(86)71713-9

16. Hamels, I. Trophic interactions between ciliates and nematodes from an intertidal flat [Text] / I. Hamels, T. Moens, K. Muylaert, W. Vyverman // Aquatic Microbial Ecology. 2001. - Vol. 26. - P. 61-72. doi: 10.3354/ame026061

17. Blinova, E. I. Macroalgal wrack: condition to the formation and the impact on the ecological state of the sea (in the case of Anapa Bay, Black Sea) [Text] / E. I. Blinova, M. Yu. Saburin // Trudy VNIRO. - 2005. - Vol. 144. P. 286-293.

18. Komissarova, N. Yu. Modern domestic and foreign production from seaweed [Text] / N. Yu. Komissarov // Overview. Fisheries. Series: Processing of fish and seafood. 1989. - Issue 4. - 45 p.

19. State Standards. Algae, sea-grass and products of their processing. Methods of analysis [Text]. - Moscow, 1984. $-53 \mathrm{p}$.

20. Methods of organic matter investigation in the ocean [Text] / E. A. Romankevich (Ed.). - Moscow: Nauka Publ., 1980. - 343 p.

21. Petkevich, T. A. Microelements in cultivated mussels of the Odessa Gulf [Text] / T. A. Petkevich // J. Ekologia moria. - 1990. - Issue 36. - P. 49-54.

22. Menkina, P. A. Organic phosphorus compounds mineralizing bacteria [Text] / P. A. Menkina // J. Microbiology. - 1950. - Vol. 19, Issue 4. - P. 308-315.

23. Bryantseva, Yu. V. Calculation of the cells volume of algae and plankton ciliates of the Black Sea. Methodological Guide [Text] / Yu. V. Bryantseva, A. V. Kurilov. - Sevastopol: IBSS, 2003. $-23 \mathrm{p}$.

24. Methods of soil mycology and biochemistry [Text]/ D. G. Zvyagintsev (Ed.). - Moscow: Moscow University Publ., 1991. -309 p.

25. Algae [Text] / S. P. Wasser, N. V. Kondratyeva (Eds.). - Kiev: Naukova Dumka Publ., 1989. - P. 176-177.

26. Arsan, O. M. Methods of hydroecological investigations of surface water [Text] / O. M. Arsan, O. A. Davydov, T. M. Dyachenko, N. Yu. Evtushenko, V. M. Zhukinsky, 
N. I. Kyrpenko; V. D. Romanenko (Ed.). - Kyiv: LOGO Publ., 2006. - P. 33-37.

27. Bryantseva, Yu. V. Calculation of volume and surface area of unicellular algae of the Black Sea [Text] / Yu. V. Bryantseva, A. M. Lyakh, A. V. Sergeeva. - Sevastopol: IBSS, 2005. $-25 \mathrm{p}$.

28. Diatoms of the USSR. Issue 1 [Text]. - Leningrad: Nauka Publ., 1974. - 116 p.

29. Asaul, Z. I. Identification guide for Euglenophyta of Ukrainian SSR [Text] / Z. I. Asaul. - Kiev, 1975. - 408 p.

30. Vetrova, Z. I. Colorless Euglenophyta of Ukraine [Text] / Z. I. Vetrova. - Kiev: Naukova Dumka Publ., 1980. $-182 \mathrm{p}$.

31. Zhukov, B. F. Atlas of freshwater heterotrophic flagellates (biology, ecology and systematics) [Text] / B. F. Zhukov. - Rybinsk: IBIW RAS, 1993. - 160 p.

32. Al-Yamani, F. Y. Illustrated Guide on the Flagellates of Kuwait's Intertidal Soft Sediments [Text] / F. Y. AlYamani, M. Saburova. - Kuwait Institute for Scientific Research, 2010. - $197 \mathrm{p}$.

33. Mylnikov, A. P. Planktonic Heterotrophic Flagellates of Small Water Bodies in the Yaroslavl Province [Text] / A. P. Mylnikov, N. G. Kosolapova, A. A. Mylnikov // J. Entomol. Rev. - 2002 - Vol. 82, Issue 1. - P. 271-280.

34. Vørs, N. Heterotrophic amoebae, flagellates and Heliozoa from the Tvarminne Area, Gulf of Finland, in 19881990 [Text] / N. Vørs // Ophelia. - 1992. - Vol. 36. - P. 1-109. doi: 10.1080/00785326.1992.10429930

35. Lee, W. J. Heterotrophic flagellates (Protista) from marine sediments of Botany Bay, Australia $[$ Text $/$ W. J. Lee, D. J. Patterson // Journal of Natural History. - 2000. - Vol. 34, Issue 4. - P. 483-562. doi: 10.1080/002229300299435

36. Uhlig, G. Eine einfache Methode zur Extraktion der vagilen mesopsammalen Mikrofauna [Text] / G. Uhlig // Helgoländer Wissenschaftliche Meeresuntersuchungen. - 1964. Vol. 11, Issue 3-4. - P. 178-185. doi: 10.1007/bf01612370

37. Foissner, W. Identification and Ecology of Limnetic Plankton Ciliates [Text] / W. Foissner, H. Berger, J. Shaumburg. - Munich: Informationsberichte des Bayer. Lamdesamtes für Wasserwirtschaft, 1999. - P. 9-26.

38. Ma, H. An improved silver carbonate impregnation for marine ciliated protozoa [Text] / H. Ma, J. K. Choi, W. Song // J. Acta Protozool. - 2003. - Vol. 42, Issue 2. P. 161-164.

39. Carey, P. G. Marine Interstitial Ciliates: An Illustrated Key [Text] / P. G. Carey. - London; New York: Chapman Hall, 1992. -351 p.

40. Mycology. Guidelines for special course under section "Ecology of fungi and fungi-like organisms" [Text]. Minsk: "Biology", 2011. -47 p.

41. Choi, H. G. Antioxidant and antimicrobial activity of Zostera marina L. extract [Text] / H. G. Choi, J. H. Lee, H. H. Park, F. A. Q. Sayegh // ALGAE. - 2009. - Vol. 24, Issue 3. - P. 179-184. doi: 10.4490/algae.2009.24.3.179

42. Stanley, M. S. Inhibition of fungal spore adhesion by zosteric acid as the basis for a novel, nontoxic crop protection technology [Text] / M. S. Stanley, M. E. Callow, R. Perry, R. S. Alberte, R. Smith, J. A. Callow // Phytopathology. 2002. - Vol. 92, Issue 4. - P. 378-383. doi: 10.1094/phyto. 2002.92.4.378

43. Harrison, P. G. Inhibition of the growth of microalgae and bacteria by extracts of eelgrass (Zostera marina) leaves [Text] / P. G. Harrison, A. T. Chan // Marine Biology. 1980. - Vol. 61, Issue 1. - P. 21-26. doi: 10.1007/bf00410338

44. Harrison, P. G. Reductions in photosynthetic carbon uptake in epiphytic diatoms by water-soluble extracts of leaves of Zostera marina [Text] / P. G. Harrison, C. D. Durance // Marine Biology. - 1985. - Vol. 90, Issue 1. - P. 117-119. doi: $10.1007 /$ bf00428222
45. Arndt, H. Functional diversity of heterotrophic flagellates in aquatic ecosystems. The flagellates: unity, diversity and evolution [Text] / H. Arndt, D. Dietrich, B. Auer, E.-J. Cleven, T. Gräfenhan, M. Weitere, A. Mylnikov; B. S. C. Leadbeater, J. C. Green (Eds.). - London; New York: Taylor and Francis, 2000. - P. 240-268.

\section{References}

1. Riedl, R. J., Machan, R. (1972). Hydrodynamic patterns in lotic intertidal sands and their bioclimatological implications. Marine Biology, 13 (3), 179-209. doi: 10.1007/ bf00391378

2. McLachlan, A., Eliot, I. G., Clarke, D. J. (1985). Water filtration through reflective microtidal beaches and shallow sublittoral sands and its implications for an inshore ecosystem in Western Australia. Estuarine, Coastal and Shelf Science, 21 (1), 91-104. doi: 10.1016/0272-7714(85)90008-3

3. McLachlan, A., Turner, I. (1994). The Interstitial Environment of Sandy Beaches. Marine Ecology, 15 (3-4), 177-212. doi: 10.1111/j.1439-0485.1994.tb00053.x

4. Snigireva, A. A., Aleksandrov, B. G. (2010). Impact of shore protection works on microflora of Odessa Gulf coast (Black Sea). Research notes of Ternopol Univ. Ser. Biol., 3, 253-256.

5. Knox, G. A. (2000). The ecology of seashores. New York: CRC Press LLC, 557. doi: 10.1201/9781420042634

6. McLachlan, A., Brown, A. C. (2006). The ecology of sandy shores. Acad. Press, Elsevier, 373.

7. Smith, B. D., Foreman, R. E. (1984). An assessment of seaweed decomposition within a southern Strait of Georgia seaweed community. Marine Biology, 84 (2), 197-205. doi: 10.1007/bf00393005

8. Mews, M., Zimmer, M., Jelinski, D. (2006). Speciesspecific decomposition rates of beach-cast wrack in Barkley Sound, British Columbia, Canada. Marine Ecology Progress Series, 328, 155-160. doi: 10.3354/meps328155

9. Koop, K., Newell, R., Lucas, M. (1982). Biodegradation and Carbon Flow Based on Kelp (Ecklonia maxima) Debris in a Sandy Beach Microcosm. Marine Ecology Progress Series 7, 315-326. doi: 10.3354/meps007315

10. MacLachlan, A., McGwynne, L. (1986). Do sandy beaches accumulate nitrogen? Marine Ecology Progress Series, 34, 191-195. doi: 10.3354/meps034191

11. Pregnall, A., Miller, S. (1988). Flux of ammonium from surf-zone and nearshore sediments in Nahant Bay, Massachusetts, USA, in relation to free-living Pilayella littoralis. Marine Ecology Progress Series, 50, 161-167. doi: 10.3354/ meps050161

12. Linley, E., Newell, R., Bosma, S. (1981). Heterotrophic Utilisation of Mucilage Released During Fragmentation of Kelp (Ecklonia maxima and Laminana pallida). I. Development of Microbial Communities Associated with the Degradation of Kelp Mucilage. Marine Ecology Progress Series, 4, 3141. doi: 10.3354/meps004031

13. Lucas, M., Newell, R., Velimirov, B. (1981). Heterotrophic Utilisation of Mucilage Released During Fragmentation of Kelp (Ecklonia maxima and Laminana pallida) II. Differential Utilisation of Dissolved Organic Components from Kelp Mucilage. Marine Ecology Progress Series, 4, 43-55. doi: 10.3354/meps004043

14. Stuart, V., Lucas, M., Newell, R. (1981). Heterotrophic Utilisation of Particulate Matter from the Kelp Laminaria pallida. Marine Ecology Progress Series, 4, 337-348. doi: $10.3354 /$ meps 004337

15. Chilton, E. W., Lowe, R. L., Schurr, K. M. (1986). Invertebrate Communities Associated with Bangia Atropurpurea and Cladophora Glomerata in Western Lake Erie. Journal of Great Lakes Research, 12 (3), 149-153. doi: 10.1016/s03801330(86)71713-9 
16. Hamels, I., Moens, T., Muylaert, K., Vyverman, W. (2001). Trophic interactions between ciliates and nematodes from an intertidal flat. Aquatic Microbial Ecology, 26, 61-72. doi: 10.3354/ame026061

17. Blinova, E. I., Saburin, M. Yu. (2005). Macroalgal wrack: condition to the formation and the impact on the ecological state of the sea (in the case of Anapa Bay, Black Sea). Trudy VNIRO, 144, 286-293.

18. Komissarova, N. Yu. (1989). Modern domestic and foreign production from seaweed. Overview. Fisheries. Series: Processing of fish and seafood, $4,45$.

19. State Standards. Algae, sea-grass and products of their processing. Methods of analysis (1984). Moscow, 53.

20. Romankevich, E. A. (Ed.) (1980). Methods of organic matter investigation in the ocean. Moscow: Nauka Publ., 343.

21. Petkevich, T. A. (1990). Microelements in cultivated mussels of the Odessa Gulf. J. Ekologia moria, 36, 49-54.

22. Menkina, P. A. (1950). Organic phosphorus compounds mineralizing bacteria. J. Microbiology, 19 (4), 308-315.

23. Bryantseva, Yu. V., Kurilov, A. V. (2003). Calculation of the cells volume of algae and plankton ciliates of the Black Sea. Methodological Guide. Sevastopol: IBSS, 23.

24. Zvyagintsev, D. G. (Ed.) (1991). Methods of soil mycology and biochemistry. Moscow: Moscow University Publ., 309.

25. Wasser, S. P., Kondratyeva, N. V. (Eds.) (1989). Algae. Kiev: Naukova Dumka Publ., 176-177.

26. Arsan, O. M., Davydov, O. A., Dyachenko, T. M., Evtushenko, N. Yu., Zhukinsky, V. M., Kyrpenko, N. I.; Romanenko, V. D. (Ed.) (2006). Methods of hydroecological investigations of surface water. Kyiv: LOGO Publ., 33-37.

27. Bryantseva, Yu. V., Lyakh, A. M., Sergeeva, A. V. (2005). Calculation of volume and surface area of unicellular algae of the Black Sea. Sevastopol: IBSS, 25.

28. Diatoms of the USSR. Issue 1 (1974). Leningrad: Nauka Publ., 116.

29. Asaul, Z. I. (1975). Identification guide for Euglenophyta of Ukrainian SSR. Kiev, 408.

30. Vetrova, Z. I. (1980). Colorless Euglenophyta of Ukraine. Kiev: Naukova Dumka Publ., 182.

31. Zhukov, B. F. (1993). Atlas of freshwater heterotrophic flagellates (biology, ecology and systematics). Rybinsk: IBIW RAS, 160.

32. Al-Yamani, F. Y., Saburova, M. (2010). Illustrated Guide on the Flagellates of Kuwait's Intertidal Soft Sediments. Kuwait Institute for Scientific Research, 197.

33. Mylnikov, A. P., Kosolapova, N. G., Mylnikov, A. A. (2002). Planktonic Heterotrophic Flagellates of Small Water
Bodies in the Yaroslavl Province. J. Entomol. Rev., 82 (1), 271-280.

34. Vørs, N. (1992). Heterotrophic Amoebae, Flagellates and Heliozoa from the Tvärminne Area, Gulf of Finland, in 1988-1990. Ophelia, 36 (1), 1-109. doi: 10.1080/00785326. 1992.10429930

35. Lee, W. J., Patterson, D. J. (2000). Heterotrophic flagellates (Protista) from marine sediments of Botany Bay, Australia. Journal of Natural History, 34 (4), 483-562. doi: 10.1080/002229300299435

36. Uhlig, G. (1964). Eine einfache Methode zur Extraktion der vagilen, mesopsammalen Mikrofauna. Helgolander Wiss. Meeresunters, 11 (3-4), 178-185. doi: 10.1007/ bf01612370

37. Foissner, W., Berger, H., Shaumburg, J. (1999). Identification and Ecology of Limnetic Plankton Ciliates. Munich: Informationsberichte des Bayer. Lamdesamtes für Wasserwirtschaft, 9-26.

38. Ma, H., Choi, J. K., Song, W. (2003). An improved silver carbonate impregnation for marine ciliated protozoa. J. Acta Protozool, 42 (2), 161-164.

39. Carey, P. G. (1992). Marine Interstitial Ciliates: An Illustrated Key. London; New York: Chapman Hall, 351.

40. Mycology. Guidelines for special course under section "Ecology of fungi and fungi-like organisms" (2011). Minsk: "Biology", 47.

41. Choi, H. G., Lee, J. H., Park, H. H., Sayegh, F. A. Q. (2009). Antioxidant and antimicrobial activity of Zostera marina L. extract. ALGAE, 24 (3), 179-184. doi: 10.4490/algae. 2009.24.3.179

42. Stanley, M. S., Callow, M. E., Perry, R., Alberte, R. S., Smith, R., Callow, J. A. (2002). Inhibition of Fungal Spore Adhesion by Zosteric Acid as the Basis for a Novel, Nontoxic Crop Protection Technology. Phytopathology, 92 (4), 378-383. doi: 10.1094/phyto.2002.92.4.378

43. Harrison, P. G., Chan, A. T. (1980). Inhibition of the growth of micro-algae and bacteria by extracts of eelgrass (Zostera marina) leaves. Marine Biology, 61 (1), 21-26. doi: 10.1007/bf00410338

44. Harrison, P. G., Durance, C. D. (1985). Reductions in photosynthetic carbon uptake in epiphytic diatoms by watersoluble extracts of leaves of Zostera marina. Marine Biology, 90 (1), 117-119. doi: 10.1007/bf00428222

45. Arndt, H., Dietrich, D., Auer, B., Cleven, E.-J., Gräfenhan, T., Weitere, M., Mylnikov, A.; Leadbeater, B. S. C., Green, J. C. (Eds.) (2000). Functional diversity of heterotrophic flagellates in aquatic ecosystems. The flagellates: unity, diversity and evolution. London; New York: Taylor and Francis, 240-268.

Дата надходження рукопису 12.05.2016

Alexandrov Boris, Director, Professor, Corresponding Member of NAS of Ukraine, Institute of Marine Biology National Academy of Scientist of Ukraine, Pushkinskaya str., 37, Odessa, Ukraine, 65011

E-mail: borys.aleksandrov@gmail.com

Dyadichko Vasiliy, Researcher, PhD, Institute of Marine Biology National Academy of Scientist of Ukraine, Pushkinskaya str., 37, Odessa, Ukraine, 65011

Garkusha Olga, Junior Researcher, Institute of Marine Biology National Academy of Scientist of Ukraine, Pushkinskaya str., 37, Odessa, Ukraine, 65011

E-mail: olga_garkusha@ukr.net

Ivanovych Galyna, Senior Researcher, PhD, Institute of Marine Biology National Academy of Scientist of Ukraine, Pushkinskaya str., 37, Odessa, Ukraine, 65011

E-mail: ivanovich526@mail.ru 
Kopytina Nadezhda, Senior Researcher, PhD, Institute of Marine Biology National Academy of Scientist of Ukraine, Pushkinskaya str., 37, Odessa, Ukraine, 65011

E-mail: kopytina_n@mail.ru

Kurilov Alexander, Head of Laboratory, PhD, Institute of Marine Biology National Academy of Scientist of Ukraine, Pushkinskaya str., 37, Odessa, Ukraine, 65011

E-mail: akur@ukr.net

Nidzvetska Lydia, Leading Engineer, Institute of Marine Biology National Academy of Scientist of Ukraine, Pushkinskaya str., 37, Odessa, Ukraine, 65011

Nikonova Svetlana, Junior Researcher, Institute of Marine Biology National Academy of Scientist of Ukraine, Pushkinskaya str., 37, Odessa, Ukraine, 65011

E-mail: niconova_s@mail.ru

Tropivska Anna, Leading engineer, Institute of Marine Biology National Academy of Scientist of Ukraine, Pushkinskaya str., 37, Odessa, Ukraine, 65011

E-mail: anna.pavlova99@gmail.com

Serbinova Irina, Leading engineer, Institute of Marine Biology National Academy of Scientist of Ukraine, Pushkinskaya str., 37, Odessa, Ukraine, 65011

УДК: 616-006:612.014.48:576.316

\title{
ХРОМОСОМНЫЕ АНОМАЛИИ В ЛИМФОЦИТАХ КРОВИ ПЕРВИЧНЫХ ОНКОЛОГИЧЕСКИХ БОЛЬНЫХ В ПОСЛЕЧЕРНОБЫЛЬСКОМ ПЕРИОДЕ
}

\author{
(C) Э. А. Дёмина
}

Выполнено ичитогенетическое обследование онкологических больных до начала противоопухолевой терапии с ичелью профилактики злокачественной трансформациии предопухолевых форм патологии. В отличие от здорового контроля, у больных раком грудной железы регистрировался повышенный уровень хромосомных обменов (1,2/100 метафаз). У больных лимфогранулематозом также обнаружен повышенный уровень аберраций хромосом за счет обменов (4/100 метафаз), являюшихся лучевыми маркерами

Ключевые слова: радиачия, предопухолевая патология, рак грудной железы, лимфогранулематоз, лимфоцииты крови, хромосомные аберрациии

This study conducted a cytogenetic examination of cancer patients prior to anti-tumor therapy in order to prevent malignant transformation of precancerous pathologies. In contrast to the control of healthy patients, a higher level of chromosomal exchanges (1.2/100 metaphases) has been registered in patients with breast cancer. It was found that the patients with Hodgkin lymphoma have elevated levels of chromosome aberrations by exchanges (4/100 metaphases), which are radiation markers

Keywords: radiation, precancerous pathology, breast cancer, Hodgkin lymphoma, lymphocytes of blood, aberrations of chromosome

\section{1. Введение}

Ионизирующие излучения (ИИ) являются одним из этиологических факторов развития рака грудной железы (РГЖ), заболеваемость которым занимает ведущее место в мире в структуре онкопатологии среди женского населения. Особенную остроту эта проблема приобрела в связи с Чернобыльской катастрофой и не утратила ее вследствие масштабности радиоактивного загрязнения территорий, в первую очередь, Украины. Возникла беспрецедентная ситуация, когда значительная часть населения Украины продолжает жить и работать в условиях длительного воздействия низких уровней ИИ [1]. Определяющую роль в инициации канцерогенеза играет нестабильность генома, что подтверждается сходством цитоге- нетических эффектов и онкогенной трансформации клеток в области действия низких доз радиации. Исследование стабильности генома и механизмов его дестабилизации у больных с пред- и опухолевой патологией грудной железы заслуживает самого пристального внимания радиобиологов и онкологов. Радиобиология располагает неоспоримыми доказательствами в пользу того, что индуцированные под влиянием облучения аберрации хромосом, образование которых связано с изменением структуры и активности онкогенов, принимают участие в злокачественной трансформации клеток. Поэтому актуальным и новым в теоретическом и практическом плане являются цитогенетические исследования, направленные на изучение стабильности генома в сравнительном 